UNTAG Law Review (ULREV)

Volume 3, Issue 2, November 2019, PP 109-119

ISSN 2549-4910 (online) \& ISSN 2579-5279 (print)

http://jurnal.untagsmg.ac.id/indeks.php/ulrev/indeks

www.fakhukum.untagsmg.ac.id

\title{
THE ROLE OF THE COMMUNITY AND \\ THE QUALITY OF VILLAGE REGULATIONS
}

Novia Ayu Permatasari, Adhitya Widya Kartika

Law Faculty of Universitas Pembangunan Nasional Veteran Jawa Timur

Email : adhityawidyakartika@ymail.com

\begin{abstract}
Society is one of the elements in the formation of legal products by the government so that the legal products that are formed do not cause harm to one or both parties. Formation of legal products or laws and regulations in order to meet legal objectives (for example justice, expediency, and legal certainty), it is also necessary that a legal product be made by an authorized official or government which by law is given the authority to form regulations laws or legal products. This is important because it relates to the relief of a legal product or the needs and issues of village law between one village and another because of the different environmental and community conditions between one village and another. Community participation in the formation of village regulations is important because the community knows about legal issues in the community, so it is important when establishing laws and regulations, especially village regulations to find out the aspirations of the village community concerned. In addition, public legal awareness is important in the context of enactment to achieve the goals of what is the goal of a legal product that is made. The method used is normative juridical approach to the legislation and the doctrine of law and using qualitative analysis.
\end{abstract}

Keywords: Village Regulation, Community, Village Government

\section{INTRODUCTION}

Legal norms that contain legal provisions are a benchmark in the concept of behavior in the community. One of the legal norms is the statutory regulations in which the laws and regulations contain provisions that limit and even encumber the rights of the community or citizens. A rule of law state in which a government action must be in accordance with the laws and regulations and one of the main principles in the rule of law is the existence of protection for the community. This is a limitation on the actions of the government for example in issuing policies so that there is no arbitrariness. This is at the same time a protection for the public or citizens so that they are not harmed by a policy carried out or formed by the government. 
Arbitration is a form of government action that can harm the community. Besides that, in the concept of state which the government has more power than the people, so the concept of limiting acts is needed so that arbitrary legal acts do not occur which end up harming the community or citizens. Therefore, the principles of limitation of authority so that they do not occur arbitrarily so that the policies made are not detrimental to the community, one of the ways is through openness for the community, one of which is related to the formation of laws and regulations.

The formation of laws and regulations that involve the community is important because the people who experience or understand what the community's needs or legal issues are are the people concerned. Because it needs to be understood that one legal product is a statutory regulation (the provisions in it) or legal norms always run behind a legal development in society. Whereas a good law or legal product or statutory provision is if it can cover developments or legal issues in the community. In addition, the needs and legal issues in a well-known community are the community concerned. In addition, the Government, namely the village government (village government) is the smallest government system that is considered to be the closest to the community because it is located in the same area, so it should be well aware of legal issues or what legal needs are in its territory. Therefore, in order to have a quality legal product, especially village regulations that can cover legal issues in the village, good communication or relationship is very important between the village government and the village community. The relationship between village government and village community is related to the government system, one of which is the participation of the community in the formation of laws and regulations in the village or the formation of policies in the village. One of the legal products is the participation of the government and village community in the formation of village regulations.

The aspirations of the community in the formation of laws and regulations are very important to get a quality law product that is good or in accordance with the needs or covers the legal needs in the community. Therefore, accommodating the aspirations of the people associated with the laws and regulations that will be formed is important. In addition, knowledge of the formation of legislation for village governments is important for the harmonization of laws between legal products, especially laws and regulations. This is for the sake of a legal certainty in the community. In addition, so that the legal requirement for the formation of a statutory regulation or the legal requirement for a statutory regulation is guaranteed. In addition to knowledge of legal formation for the government, it is also important to know about the formation of laws and regulations for the village community. This is because the community has a supervisory role related to the formation and implementation of a legal product formed by the government. This is due to the lack of a community's role in the formation of a legal 
product, one of which is legislation in particular is that village regulations can lead to less coverage of village regulations as a solution or solution related to legal problems in the community. Another important thing is the need for community legal awareness to realize quality law. Therefore, it is important to discuss how important community participation is for the quality of village regulations that specialize in research results in villages in Sekaran Subdistrict, Lamongan Regency, East Java Province.

\section{Problem}

Formulation The formulation of the problem that can be drawn from the background above is how important is the role of the community for the quality of village regulations?

\section{Research Methods}

Articles compiled in this journal are legal research articles which are the results of research in the field of law. This article is related to research relating to village government and the formation of laws and regulations at the village level, one of which is village regulations. This relates to the importance of information regarding the formation of legislation specifically related to village regulations conveyed to the village government and the village community so that villagers are aware of the formation of legislation. This is related to the quality of laws and regulations, especially village regulations that will be formed. This is related to community participation in the quality of village regulations. Research related to the importance of community participation for the quality of laws and regulations, especially village regulations using a legal research method called empirical legal research or socio legal research or field studies, but the analysis in this journal article uses normative juridical legal research methods or the use of analysis in library studies. This article analyzes the legal problem using various approaches including the statutory regulatory approach which uses the statutory regulation to analyze the legal issues in this article. Besides analyzing legal issues using the doctrinal approach that exists in legal science, the purpose is to analyze the data that has been obtained using doctrines that are related to the opinions of experts in the field of law. The analysis that uses the approach of laws and doctrines of the law is related to village governance, also related to village regulations, in addition to doctrines relating to the formation of laws and regulations, and so on. This approach is of course related to the field of law, especially with regard to community participation in the quality of village regulations. This article uses the method of analyzing legal issues using qualitative analysis. This qualitative analysis uses the method of analysis with or with regard to primary data and secondary data, but specifically this article which is the result of the study then uses secondary data. Basically the use of this qualitative analysis method by taking secondary data and then analyzed qualitatively. After that is arranged systematically then the last is drawing conclusions in accordance with the main issues or legal issues. This article is the result of 
research conducted in villages in Sekaran Subdistrict, Lamongan Regency, East Java Province.

\section{Discussion}

The concept of a state is essentially a state based on law. Aristotle's opinion on elements of constitutional government that government is implemented according to law. Aristotle, there are also three elements of constitutional government namely (one of them) is that the government is carried out according to the law which is based on general provisions, not arbitrarily created laws that override conventions and constitutions. ${ }^{1}$ This means that when the government runs a government such as carrying out a government action, the act must be in accordance with applicable law. This means that a government activity has a limit so that what is done by the government must not violate the law (for example: legislation). The nature of the rule of law is expected to be a reduction of arbitrary actions carried out by the authorities, even the provisions are intended so that an action taken by the government is avoided arbitrary. The rule of law in Indonesia is regulated in Article 1 paragraph (3) of the 1945 Constitution of the Republic of Indonesia. The article stipulates that the State of Indonesia is a state of law. This has the understanding that the Indonesian state, especially the government in carrying out its government must be based on law. A country when referring to a rule of law, the rule of law in the world has various types of rule of law. Types of legal countries include the Islamic Nomocracy State Law, the Continental European State Law (Rechtsstaat), the Anglo Saxon State Law (Rule of Law), the Socialist Legality State of Law, the State Law International Commission of Jurist, the State of Law of Indonesia, and the State of Law of Pancasila. ${ }^{2}$ The concept of the rule of law of Indonesia and the rule of law of Pancasila is that there is a relationship of definition when referring to the definition that was brought up by Philipus M. Hadjon who mentioned that the type of law state in Indonesia is the Pancasila law state. ${ }^{3}$ The concept of the rule of law in Indonesia is different in the meaning of the normative diction of the constitution in the 1945 Constitution of the Republic of Indonesia before the amendment to the 1945 Constitution of the Republic of Indonesia after the amendment. In the 1945 Constitution of the Republic of Indonesia prior to the amendment to the concept of the rule of law found in the Explanation of the 1945 Constitution of the Republic of Indonesia in the Roman Government System number 1 that the Indonesian State is based on Law (Rechtsstaat), not based on mere power (Machtsstaat). This means that the type of rule of law used in the government system at that time was the type of the rule of law Rechtsstaat not another system

1 Firman Freaddy Busroh. 2016. Teknik Perundang-undangan (Suatu Pengantar). Cintya Press. Jakarta. p. 23.

2 A. Muin Fahmal. 2006. Peranan Asas-asas Umum Pemerintahan yang Layak dalam Mewujudkan Pemerintahan yang Bersih. UII Press. Yogyakarta. p. 75. dan Putera Astomo. 2018. Ilmu Perundangundangan Teori dan Praktik di Indonesia. Depok. Rajawali Press. p. 41.

3 A. Ph. Idenberg. 1983. De Nagen van de Verzorgingstaat Kansen en Prespectiven vor Morgen. Amsterdam. Meulenhoff Informatief. p. 82. 
and the Indonesian system of government should be guided by that provision. It is different when the 1945 Constitution of the Republic of Indonesia after the Amendment that the concept of the rule of law used by the Indonesian state is contained in Article 1 paragraph (3) of the 1945 Constitution of the Republic of Indonesia that the State of Indonesia is a constitutional state. Thus, the politics of law in Indonesia regarding the concept ofis to combine two elements, both rechtsstaat and the rule of law the rule of law, or even other legal systems at once. ${ }^{4}$ This means that the concept of the rule of law applied to the government system in Indonesia is not limited to the legal state system rechtsstaat as in the 1945 Constitution of the Republic of Indonesia prior to the Amendment but the type of rule of law adopted can include elements found in the state other laws that are consistent with Indonesian characteristics (for example, may not conflict with Pancasila). This is because the rule of law state in Article 1 paragraph (3) of the 1945 Constitution of the Republic of Indonesia is a diction that can be defined as a diction in general because it does not refer to the diction of the concept of a particular rule of law type.

The community is one element in the formation of legal products by the government so that the legal products that are formed do not cause harm to one or both parties. The concept of the rule of law has perfected that the concept of the rule of law has elements including the real role of community members or citizens to participate in overseeing the actions and implementation of policies carried out by the government. ${ }^{5}$ It should be understood that the making of legal products carried out by the government may be arbitrary. Therefore, the making of legal products by the government including policies must be limited by law. The limitation by law can be done by establishing norms in the constitution or other laws and regulations which become guidelines for the government to carry out its obligations. This is a discussion related to in order to avoid an arbitrariness, it is necessary to limit the authority, one of which is the regulation or restriction of government actions through the provisions or norms in the legislation. The law is the essence of the code of conduct not only to limit the government but also for public order and has the purpose of one of them being the existence of justice, expediency, and legal certainty felt by the community in the state. Therefore the role of the government and the community is important in realizing a just state law like what is the goal of the Indonesian state. The urgency of community participation in the formation of law in a theoretical perspective according to Steven Vago includes rationalistic models, functionalist views, conflict theories, and moral entrepreneurship theses. This discussion can refer to Steven Vago's theory of rationalistic models and functionalist views. ${ }^{6}$ Steven Vago's opinion that the

4 Moh. Mahfud MD. 2007. Perdebatan Hukum Tata Negara. Pasca Amandemen Konstitusi. LP3ES. Jakarta. p. 50.

5 Ridwan HR. 2013. Hukum Administrasi Negara Edisi Revisi. Jakarta. Rajawali Press. p. 5.

6 Steven Vago.1997. Law and Society.Englewood Cliffs. New Jersey. Prentice Hall Inc. p. 155. 
rationalistic model puts forward that a law is formed has the aim to protect the community. Steven Vago's functionalistic view emphasizes how law arises where a law stems from a habit then crystallized in the form of norms. This is also related to the concept of socio-legal sources that come specifically from people's lives.

The legal source basically consists of two main sources, namely the source of material law and the source of formal law. The nature of legal sources in general, according to Sudukno Mertokusumo, referred to as sources of law can be understood as, among other things: as a legal principle, showing the previous law that provides material to the current law, the source of the law's enactment, the source from which the law is recognized, as the source of the law's occurrence. $^{7}$ The role of the community in the formation of law can be found in the classification of legal sources, namely in material legal sources. Material legal sources are legal sources that contain or consist of community factors that influence the formation of law (influence on legislators, influence on judges' decisions, and so on). ${ }^{8}$ The source of material law itself is divided into several categories such as historical legal sources, sociological legal sources, and philosophical legal sources. ${ }^{9}$ The source of law is sociologically a rule of law that reflects the living conditions in society in the form of needs or demands or problems that exist in society. The source of sociological law which is the source of law which constitutes legal materials included in legal norms which is a solution of the conditions that exist in society, this significantly indicates the need for the role of the community to know the factors that exist in society. Therefore, the formation of laws and regulations or legal products is expected to be in accordance with the reality of people's lives. In addition, because the development of problems in society is faster than the norms listed in the law itself, it is increasingly important for people to participate in the formation of legislation or the formation of legal products so that the resulting legal products really know what the problems are in the community so that the resulting legal products can be used as a solution to the problems that exist in society.

A society when running its life has a relationship with the norm, because every human being has a sense of mutual protection for his rights so that a society must have benchmarks so that one person with another person does not harm each other and community life runs orderly so that welfare arises because arises a sense of security in a person when they are in a community environment to run a social life. Mochtar Kusumaatmaadja, in order to achieve order, there is an effort to ensure legal certainty in human relations in society, because it is impossible for humans to develop talents and abilities given by God to them optimally without the certainty of law and order. ${ }^{10}$ Norms are essentially a measure that must be obeyed by someone in relation to

7 Bagir Manan. 1987. Konvensi Ketatanegaraan. Bandung. Armico. p. 9-10.

8 NEAlgra, et. al. 1983. Mula Hukum. Bandung. Bina cipta. p. 16.

9 Ridwan HR.2013. Hukum Administrasi Negara Edisi Revisi. Jakarta.Rajawali Press. p.56-58.

10 Mochtar Kusumaatmadja.1997. Pengantar Ilmu Hukum, Satu Pengenalan Pertama Ruang Lingkup Berlakunya Ilmu Hukum. Bandung. Unpad Press. p. 3. 
each other or the environment. ${ }^{11}$ If it is seen from the legal source of a regulation, it can arise representative or desire or arise from the community, for example there is a habit that repeatedly becomes a benchmark or a joint guideline, then the community agrees to be used as a guideline and then stated in the form of norms.

Maria Farida Indrati, law is a right angle of social behavior which has the binding force for the object of laws or norms that have legality and are valid at that time. The law itself is related to the values? ? that live in society. Value is the difference between which is good and which is bad. These values? ? then become the guideline of society and there are similarities so that the norm becomes a guideline that the nature of one's bonds becomes stronger than just values. A life in society there are various kinds of norms. Norms that live in the community itself depend on aspects of personal life and interpersonal aspects of life. The norms that live in society consist of various kinds of norms including the religious norms, the nudity norms, the modesty norms, and the legal norms. The rule of law is a rule that has a stronger legal force when compared with other rules that live in society (such as religious rules, rules of decency, rules of decency). The difference between the rule of law and other rules such as the rules of religion, the rules of decency, the rules of decency although both are guidelines for behavior is to have sanctions. The rule of law itself is coercion from outside, not from the self which has sanctions and coercion is carried out by the state apparatus. The difference with other rules such as the rules of religion, the rules of decency, the rules of decency which are like the rules of religion, the rules of decency, the rules of politeness that force comes from oneself or from the community. Therefore, the most binding binding rule is the rule of law because there are sanctions and coercion by government officials and witnesses referred to are direct, so the value will be high or strong (what is meant) by the force of law if it is set forth in the form of legal norms or legal norms. In addition, those who know about the development of society other than by the government but also the community, it becomes important for the community to participate such as giving aspirations and obtaining transparency in relation to its implementation (related to supervision carried out by the community) because the law must always be able to reach how the community develops while the development society so fast. In addition, the purpose of the law is that there is no arbitrariness carried out by the government and guarantees the happiness of the community which means there is protection for the community.

Formation of legal products or laws and regulations in order to meet legal objectives (for example justice, expediency, and legal certainty), it is also necessary that a legal product be made by an authorized official or government which by law is given the authority to form regulations laws or legal products. This is important because it relates to the relief of a legal

11 Maria Farida Indrati S. 2014. Ilmu Perundang-Undangan I: Jenis, Fungsi, dan Materi Muatan. Yogyakarta. Kanisius. p. 18. 
product or statutory regulation. The legality of laws and regulations (for example, related to the legality of village regulations) is important. There is a measure of legal science that a statutory regulation applies whether or not. The measure of the enactment of these laws and regulations, among others, have a legal basis, have a sociological basis, have a philosophical and legal basis. One of them is juridical validity or can be said as normative enforceability is the validity of a legal norm with its binding power to the public as a dogma which is seen from judicial technical considerations. ${ }^{12}$ Juridical enforcement itself which is a measure of the enactment of laws and regulations has requirements. Bagir Manan, the requirements for juridical enactment are as follows: $:^{13}$

1. The necessity of the authority of the legislators.

2. The necessity of conformity with the form or type or regulation of the law with the material that is regulated, especially if ordered by a higher level law or equivalent.

3. Must follow certain procedures.

4. The requirement does not contradict the higher level regulations.

One of the requirements for juridical enforcement is the existence of mandatory authority from the legislators. This means that all forms of legislation or legal products produced must be made by an authorized official. An official or government when issuing a legal product or forming a legal product must have authority over it, the authority itself is a government foundation in carrying out a government act, one of which is to form a legal product. The authority is the legal basis for the government to carry out a government action that can cause or have legal consequences. Therefore, if a legal product is made by the government if it does not have a legal basis, then the legal act in the form of the determination of the legal product or the statutory regulations or the legal product formed earlier is null and void. In addition to forming a legal product, it is necessary to comply with certain procedures. Likewise in the formation of village regulations. Thus, the formation of village regulations must fulfill this (among other things: the necessity of the existence of authority from the makers of laws and regulations, the necessity to follow certain procedures). Whatever the concept of value in order to meet or there is legalization of (being a legal product that has a legal binding capacity) it must meet these 4 (four) conditions. If it does not meet these requirements, the nature of the legal product established by the government does not have a binding capacity for its target because it is essentially null and void. This also applies to village regulations or other regulations or other legal products established by the village government.

The needs and issues of village law differ from one village to another because of the different environmental and community conditions between one village and another. The formation of

12 Jimly Asshiddiqie. 2011. Perihal Undang-Undang. Jakarta. Rajawali Press. p. 167.

13 Sirajuddin. Et.al. 2016. Legislative Drafting. Pelembagaan Metode Partisipatif dalam Pembentukan Peraturan Perundang-undangan. Poor. Setara Press. p. 22. 
village regulations can be said as or is one of the ways or solutions to the problems and needs of the village thus the formation of village regulations should be adjusted to the situation and conditions as well as problems or problems in the village. Thus it will be important to know how the situation and conditions as well as the needs and problems that exist in the village. It is important to know when the formation of laws and regulations so that the formation of legal products such as village regulations are regulations or legal products that can cover problems in the village. Likewise, when establishing village regulations in villages in Sekaran District, Lamongan Regency, East Java Province. So it is important for the formation of village regulations is to express the aspirations or to know the aspirations of the people involved because of knowledge about what is needed in village governance. Likewise, when there are proposals from the government, it is necessary to obtain approval from the community for legitimacy regarding village regulations. Must meet the procedures for the formation of village regulations. In addition, obligations that are burdensome and have sanctions need to be legitimized into village regulations or other legal products formed by the village (constituting legal norms) in order to have the allure so that sanctions included in norms can be enforced. But in the villages in Sekaran Subdistrict, Lamongan Regency, East Java Province, there are several provisions that have not been set forth in the form of village regulations (or other legal products that are the legal norm).

Public legal awareness is important in the context of enactment to achieve the goals of what is the goal of a legal product that is made. Public legal awareness is related to cultural factors which is one of the factors in law enforcement theory that was raised by Lawrence $\mathrm{M}$. Friedman. ${ }^{14}$ Cultural factors in the opinion of Lawrence M. Friedman are meant cultural factors that are seen from aspects of human attitudes and the legal system - beliefs, avoided or misused. This relates to the legal culture in society where social thoughts or social factors also determine. This is related to how the law is used, how the law is avoided and how the law is abused. This means that without a culture of law, the law becomes helpless because the law is also related to human social factors whether humans or the community will apply the law or whether the community is not submissive or disobedient to the law or the community is looking for a gap from the law. Therefore, it is important in involving the community in the formation of laws and regulations, especially village regulations because the community is a party who understands the legal issues that develop in the community, besides the laws and regulations related to village regulations, if there is community participation, of course there will be protection community because there is actually the purpose of the formation of the law in addition to realizing the principles of justice, expediency, and legal certainty.

14 Lawrence M. Friedman. 1975. The Legal System: Sociaal Science Perspective. New York. Russel sage Foundation. 


\section{Conclusion}

The concept of a state in Indonesia is essentially a state based on law. The community is one element in the formation of legal products by the government so that the legal products that are formed do not cause harm to one or both parties. The legal source basically consists of two main sources, namely the source of material law and the source of formal law. A society when running its life has a relationship with the norm, because every human being has a sense of mutual protection for his rights so that a society must have benchmarks so that one person with another person does not harm each other and community life runs in an orderly manner so that welfare arises because arises a sense of security in a person when they are in a community environment to run a social life. Maria Farida Indrati, law is a right angle of social behavior which has the binding force for the object of laws or norms that have legality and are valid at that time. Formation of legal products or laws and regulations in order to meet legal objectives (for example justice, expediency, and legal certainty), it is also necessary that a legal product be made by an authorized official or government which by law is given the authority to form regulations laws or legal products. This is important because it relates to the relief of a legal product or the needs and issues of village law between one village and another because of the different environmental and community conditions between one village and another. Community participation in the formation of village regulations is important because the community knows about legal issues in the community, so it is important when establishing laws and regulations, especially village regulations to find out the aspirations of the village community concerned. In addition, public legal awareness is important in the context of enactment to achieve the goals of what is the goal of a legal product that is made.

\section{References}

A. Muin Fahmal. 2006. Peranan Asas-asas Umum Pemerintahan yang Layak dalam Mewujudkan Pemerintahan yang Bersih. UII Press. Yogyakarta.

A. Ph. Idenberg. 1983. De Nagen van de Verzorgingstaat Kansen en Prespectiven vor Morgen. Amsterdam. Meulenhoff Informatief.

Bagir Manan. 1987. Konvensi Ketatanegaraan. Bandung. Armico.

Firman Freaddy Busroh. 2016. Teknik Perundang-undangan (Suatu Pengantar). Cintya Press. Jakarta.

Jimly Asshiddiqie. 2011. Perihal Undang-Undang. Jakarta. Rajawali Press.

Lawrence M. Friedman. 1975. The egal System: Sociaal Science Perspective. New York. Russel sage Foundation. 
Maria Farida Indrati S. 2014. Ilmu Perundang-Undangan I: Jenis, Fungsi, dan Materi Muatan. Yogyakarta. Kanisius.

Moh. Mahfud MD. 2007. Perdebatan Hukum Tata Negara. Pasca Amandemen Konstitusi. LP3ES. Jakarta.

Mochtar Kusumaatmadja. 1997. Pengantar Ilmu Hukum, Satu Pengenalan Pertama Ruang Lingkup Berlakunya Ilmu Hukum. Bandung. Unpad Press.

NEAlgra, et. al. 1983. Mula Hukum. Bandung. Bina cipta.

Putera Astomo. 2018. Ilmu Perundang-undangan Teori dan Praktik di Indonesia. Depok. Rajawali Press.

Ridwan HR.2013. Hukum Administrasi Negara Edisi Revisi. Jakarta.Rajawali Press.

Sirajuddin. Et.al. 2016. Legislative Drafting. Pelembagaan Metode Partisipatif dalam Pembentukan Peraturan Perundang-undangan. Poor. Setara Press.

Steven Vago.1997. Law and Society.Englewood Cliffs. New Jersey. Prentice Hall Inc.

Undang-Undang Repubik Indonesia Nomor 32 Tahun 2004 tentang Pemerintahan Daerah 32/04 Lembaran Negara Republik Indonesia Tahun 2004 Nomor 125, Tambahan Lembaran Negara Republik Indonesia Nomor 4437

Undang-Undang Republik Indonesia Nomor 12 Tahun 2011 tentang Pembentukan Peraturan Perundang-undangan 12/11 Lembaran Negara Republik Indonesia Tahun 2011 Nomor 82, Tambahan Lembaran Negara Republik Indonesia Nomor 5534

Undang-Undang Republik Indonesia Nomor 6 Tahun 2014 tentang Desa 6/2014 Lembaran Negara Republik Indonesia Tahun 2014 Nomor 7, Tambahan Lembaran Negara Republik Indonesia Nomor 5495.

Peraturan Pemerintah Republik Indonesia Nomor 43 Tahun 2014 tentang 43/2014 Lembaran Negara Republik Indonesia Tahun 2014 Nomor 123, Tambahan Lembaran Negara Republik Indonesia Nomor 5539 